\title{
Prevalence and antibiotic susceptibility of Salmonella spp. from water sources in Tamale, Ghana
}

\author{
Frederick Adzitey, Charles Kwaku Nunana Ashiagbor and Haruna Abu \\ Department of Animal Science, Faculty of Agriculture, University for Development Studies, Tamale, Ghana. \\ Corresponding author: Frederick Adzitey, e-mail: adzitey@yahoo.co.uk, \\ CKNA: cashiabor@yahoo.com, HA: harunaabu81@yahoo.com \\ Received: 30-06-2016, Accepted: 07-09-2016, Published online: 16-09-2016
}

How to cite this article: Adzitey F, Ashiagbor CKN, Abu H. Prevalence and antibiotic susceptibility of Salmonella spp. from water sources in Tamale, Ghana. Int J One Health 2016;2:24-28.

\begin{abstract}
Aim: This study investigated the prevalence and antibiotic resistance of Salmonella species isolated from drinking water sources in Tamale Metropolis.

Materials and Methods: Isolation of Salmonella species from 275 different drinking water samples (25 each from dam, well, rain, and bottle, 35 from tap, 40 from water trough, and 100 from sachet) was done using a slightly modified method of the Bacteriological Analytical Manual of the Food and Drugs Administration, USA. 34 Salmonella species isolated from the water samples were examined for their susceptibility to nine different antibiotics using the disc diffusion method. The study was carried out from July 2014 to January 2015.

Results: The overall prevalence of Salmonella species was 4.36\% (12/275). Dam 16.00\% (4/25) and well 16.00\% (4/25) water samples were the most contaminated source, followed by rain water (stored) $12.00 \%(3 / 25)$ and tap water samples $2.86 \%(1 / 35)$. There were no significant differences among water samples which were positive for Salmonella species $(\mathrm{p}>0.05)$; however, dam and well samples that were positive for Salmonella species differ significantly $(\mathrm{p}<0.05)$ from bottle water, sachet water, and water trough samples, which were negative for Salmonella species. The 34 Salmonella isolates were highly resistant to erythromycin (E) (100\%) and vancomycin (VA) $(94.12 \%)$. Few isolates exhibited intermediate resistances to ceftriaxone (CRO) (17.65\%), gentamicin $(\mathrm{CN})(17.65 \%)$, tetracycline $(14.71 \%)$, chloramphenicol $(\mathrm{C})(5.88 \%)$, ciprofloxacin (CIP) (2.94\%), and amoxicillin (AMC) (2.94\%). Salmonella isolates also exhibited six different antibiotic resistant patterns (VA-E, VA-E-AMC, VA-E-CRO, VA-E-C, VA-E-CRO-AMC, and VA-E-AMC-CN). The resistant pattern VA-E (with multiple antibiotic resistance index of 0.22) was the commonest.

Conclusion: This study indicated that some drinking water sources for humans and animals in Tamale Metropolis are contaminated with Salmonella species which exhibited varying resistance to various antibiotics. Therefore, consumers of water at the Tamale Metropolis are at risk of Salmonella infection from drinking water from positive water sources in the Tamale Metropolis.
\end{abstract}

Keywords: antibiotics, drinking water, public health, Salmonella species.

\section{Introduction}

Water is very essential for the existence of humans and other forms of life on earth [1]. It is involved in the normal functioning of cells that make up humans and all living organisms [2,3]. Water also helps to remove waste, lubricates joints, serve as a major component of blood, and a necessary medium for many chemical reactions that help in the formation of meat, eggs, and other animal and plant foods [4]. Potable water is expected to be odorless, tasteless, free from toxic substances, microbial and chemical contaminations [2,5]. Water is also known to be the dwelling place for most bacteria and other microorganisms which cause a variety of waterborne infections such as cholera, typhoid, bilharzia, and malaria $[6,7]$.

Copyright: Adzitey, et al. This article is an open access article distributed under the terms of the Creative Commons Attribution 4.0 International License (http://creativecommons.org/licenses/ by/4.0/), which permits unrestricted use, distribution, and reproduction in any medium, provided you give appropriate credit to the original author(s) and the source, provide a link to the Creative Commons license, and indicate if changes were made. The Creative Commons Public Domain Dedication waiver (http:// creativecommons.org/ publicdomain/zero/1.0/) applies to the data made available in this article, unless otherwise stated.
Salmonella species are Gram-negative facultative anaerobe bacteria and have been isolated from humans, animals, and the environment [8-14]. Salmonellae are among the major pathogenic bacteria in humans as well as in animals $[15,16]$. They are the leading cause of acute gastroenteritis in several countries and salmonellosis remains an important public health problem worldwide [15]. In Canada, 8.5\% (342) of river water samples were contaminated with Salmonella species which were influenced by rainfall runoff and drainage from agricultural land [17]. In Czech, 16\% (87) of pond water samples were contaminated with Salmonella species [18]. In South Africa, the prevalence rate of Salmonella species in different river samples ranged from 33-90\% [19]. A study by Akinyemi et al. [20] in Nigeria indicated that Salmonella was present in water samples. Hitherto published work on the isolation and antibiotic resistance of Salmonella species in Ghana appears to be unavailable. Antibiotics continue to play a very important role in decreasing diseases, illness and/or death associated with bacterial infections [21]. Human activities have been largely linked to the emergence of multidrug resistance isolates [16,22]. 
Salmonella species isolated from water samples were resistant to 2 or more antibiotics [21]. This study was conducted to find out whether drinking water sources in the Tamale, Metropolis of Ghana are contaminated with Salmonella species. The study also investigated the antibiotic resistance of the Salmonella species isolated from the water samples.

\section{Materials and Methods}

\section{Ethical approval}

All samples were collected as per the standard sample collection procedure without harming humans or animals.

\section{Location of study}

The study was conducted in Tamale Metropolis. Tamale is the capital town of the Northern Region of Ghana. It is located within the Guinea Savannah belt. Tamale is the third most populous settlement in Ghana, in terms of population, with a population of 537,986 people [23]. Tamale Metropolis can be located on longitude $09^{\circ} 24^{\prime} 27^{\prime \prime}$ North and latitude $00^{\circ} 51^{\prime} 12^{\prime \prime}$ West [23]. The Tamale Metropolis occupies approximately $750 \mathrm{~km}^{2}$, which is $13 \%$ of the total area of the Northern Region [23].

\section{Sample collection}

A total of 275 water samples were sampled. These water samples were collected aseptically from dam $(n=25)$, well $(n=25)$, rain $(n=25)$, tap $(n=35)$, bottle $(n=25)$, sachet $(n=100)$, and water trough $(n=40)$. The water samples were stored at $4^{\circ} \mathrm{C}$ and transported to the Spanish Laboratory of University for Development Studies, Nyankpala, Ghana, where analysis was carried out immediately upon arrival for the presence of Salmonella species.

\section{Bacteriological analysis}

Analyses for Salmonella species were done using a modified method according to the Bacteriological Analytical Manual of the Food and Drug Administration [8]. $500 \mathrm{ml}$ of the various water samples were obtained and thoroughly mixed. $1 \mathrm{ml}$ of water was taken from the $500 \mathrm{ml}$, transferred into $10 \mathrm{ml}$ buffered peptone water, and incubated at $37^{\circ} \mathrm{C}$ for $24 \pm 2 \mathrm{~h}$. Afterward, $0.1 \mathrm{ml}$ and $1 \mathrm{ml}$ of pre-enriched aliquots were transferred into $10 \mathrm{ml}$ Rappaport and Vassiliadis broth and $10 \mathrm{ml}$ selenite cystine broth, respectively. Enrichment samples in Rappaport and Vassiliadis broth were incubated at $42^{\circ} \mathrm{C}$ for $24 \mathrm{~h}$ while that of the selenite cystine broth were incubated at $37^{\circ} \mathrm{C}$ for $24 \mathrm{~h}$. Enriched aliquots (ca. $10 \mu \mathrm{l}$ ) were then streaked onto xylose lysine deoxycholate and brilliant green bile agar and incubated at $37^{\circ} \mathrm{C}$ for 24-48 h. Presumptive Salmonella species were purified on nutrient agar and were identified and confirmed using Gram-staining, biochemical tests, and Salmonella latex agglutination test. All incubations were done under aerobic condition, and all media used were purchased from Oxoid, Oxoid Limited, Basingstoke, UK.

\section{Antimicrobial susceptibility of Salmonella species}

The disk diffusion method of Bauer et al. [24] was used to determine the antibiotic resistance of 34 Salmonella species against the following antibiotics: Amoxicillin/clavulanic acid (AMC) $30 \mu \mathrm{g}$, chloramphenicol (C) $30 \mu \mathrm{g}$, gentamicin (CN) $10 \mu \mathrm{g}$, ceftriaxone (CRO) $30 \mu \mathrm{g}$, ciprofloxacin (CIP) $5 \mu \mathrm{g}$, erythromycin (E) $15 \mu \mathrm{g}$, sulfamethoxazole/trimethoprim (SXT) $22 \mu \mathrm{g}$, tetracycline (TE) $30 \mu \mathrm{g}$, and vancomycin (VA) $30 \mu \mathrm{g}$. The disks were purchased from Oxoid Limited, Basingstoke, UK. Pure cultures of Salmonella species were grown overnight in tryptic soy broth (TSB) (Oxoid Limited, Basingstoke, UK) at $37^{\circ} \mathrm{C}$ and the concentration adjusted using sterile TSB until a $0.5 \mathrm{McF}$ arland turbidity was attained. About $100 \mu \mathrm{l}$ of the culture was then swabbed onto Mueller-Hinton agar (Oxoid Limited, Basingstoke, UK) using a sterile cotton swab. Three antimicrobial disks were placed on the surface of the agar plate at a distance to avoid overlapping of inhibition zones. The plates were incubated at $37^{\circ} \mathrm{C}$ for $16-18 \mathrm{~h}$, and the results were interpreted as sensitive, intermediate, or resistance according to the Clinical and Laboratory Standards Institute Guidelines [25]. The multiple antibiotic resistance (MAR) index was calculated and interpreted according to Krumperman [26] using the formula: $a / b$, where "a" represents the number of antibiotics to which a particular isolate was resistant and "b" the total number of antibiotics tested.

\section{Statistical analysis}

The data obtained were analyzed using the generalized linear model of Statistical Package for the Social Sciences (SPSS) Version 17.

\section{Results}

The results for the occurrence of Salmonella species in water samples examined in the Tamale Metropolis are presented in Table-1. The overall prevalence of Salmonella species was $6.36 \%(12 / 275)$. Dam (16.00\%) and well (16.00\%) water samples were the most contaminated source, followed by rain water $(12.00 \%)$ and tap water samples $(2.86 \%)$. Bottle, sachet, and water trough samples recorded $0.00 \%(0 / 25),(0 / 100)$, and $(0 / 40)$, respectively. There were no significant differences among water samples which were positive for Salmonella species $(\mathrm{p}>0.05)$;

Table-1: Distribution of Salmonella species in the various drinking water sources tested.

\begin{tabular}{lccc}
\hline $\begin{array}{l}\text { Sources of } \\
\text { drinking water }\end{array}$ & $\begin{array}{c}\text { Number of } \\
\text { samples } \\
\text { tested }\end{array}$ & $\begin{array}{c}\text { Number of } \\
\text { samples } \\
\text { positive }\end{array}$ & $\begin{array}{c}\text { Percentage } \\
\text { prevalence }\end{array}$ \\
\hline Dam water & 25 & 4 & 16.00 \\
Well water & 25 & 4 & 16.00 \\
Rain water & 25 & 3 & 12.00 \\
Tap water & 35 & 1 & 2.85 \\
Bottle water & 25 & 0 & 0.00 \\
Sachet water & 100 & 0 & 0.00 \\
Water trough & 40 & 0 & 0.00 \\
Total & 275 & 12 & 4.36 \\
\hline
\end{tabular}


however, dam and well water samples that were positive for Salmonella species differ significantly $(p<0.05)$ from bottle water, sachet water, and water trough samples.

The antibiotic susceptibility test of the Salmonella isolates is shown in Table-2. Resistant to E and VA was $100 \%$ and $94.12 \%$, respectively. None of the Salmonella isolates was resistant to SXT, TE, and CIP, even though intermediate resistances occurred for TE (14.71\%) and CIP (2.94\%). Most of the isolates were highly susceptible to C (91.18\%), CN (79.41\%), AMC acid $(73.53 \%)$, and CRO (70.59\%).

The 34 Salmonella isolates also exhibited six different antibiotic resistant patterns. 23 of the isolates exhibited a resistant pattern of VA-E with MAR index of 0.22 , five exhibited a pattern of VA-E-AMC with MAR index of 0.33 , two isolates exhibited a pattern of VA-E-CRO with MAR index of 0.33 , one exhibited a pattern of VA-E-C with a MAR index of 0.33 , two exhibited a pattern of VA-E-CRO-AMC with MAR index of 0.44 , and one exhibited a pattern of VA-EAMC-CN with MAR index of 0.44 (Table-3).

\section{Discussion}

Of the 275 different drinking water samples examined, 12 were positive for Salmonella species. The occurrence of Salmonella species was highest in dam and well water samples, followed by rain and tap water samples. The presence of Salmonella species in dam, well, rain, and tap water samples is worrying since the majority of the people and animals in the Tamale Metropolis, and its environs drink from them. It was observed that dams which were positive for Salmonella species were closer to human settlement and under high utilization by humans and animals. Some of the wells which were contaminated with Salmonella species were shallow, without proper cover and the containers used for fetching water from them were dirty and left on the ground. In this study, we collected rain water from stored containers/tanks and directly from the sky and roof (aluminum sheet) during raining. Water samples collected directly from the roof and the sky were negative for Salmonella species. Rainwater samples that were contaminated with Salmonella species were collected from storage containers/tanks. Containers used for fetching water from these storage containers/tanks were also sometimes dirty, left on the ground and reuse without washing. The containers used for fetching water from wells and storage tanks can easily get contaminated by soil and/or feces of domestic animals which were observed roaming around the wells and storage tanks in search of water. Ghana Water Company supplies water (tap water) to the various households in Tamale and its environs. This company ensures that the water supplied to consumers is of good quality without any contamination. One tap water sample collected from a chop bar was contaminated with Salmonella species. This contamination may be as a result of unhygienic handling of tap and personal hygiene of consumers. Indiscriminate defecation by humans and animals in and around water bodies can cause contamination of drinking water sources such as dams and wells. Dirts, chemicals, and/or feces created by humans and/or animal activities around water bodies can be washed back into these water bodies (dams and wells), especially by rains. Variation in the level of microorganisms in water bodies can be attributed to indiscriminate human and animal feces around such water bodies [27]. Salmonella species were not isolated from bottle water (four different brands), sachet water (four different brands), and water trough (from ruminant and poultry farms). This indicates that the bottle and sachet water samples were treated and packaged under good sanitary conditions without fecal or environmental contamination. The World Health Organization [28] reported that good quality drinking water should be free from microbial contamination. The absence of Salmonella species in the water trough samples could be attributed to the fact that appropriate management practices are being carried out at the farms visited. Frequent change of water and cleaning of water troughs create a good hygienic and sanitary condition which will prevent bacteria contamination and growth.

Around 34 Salmonella species isolated from the drinking water sources in the Tamale Metropolis were examined for their susceptibility to nine different antibiotics. They were highly resistant to E $(100.00 \%)$ and VA $(94.12 \%)$. Resistance to AMC was $23.53 \%$. Few isolates also exhibited intermediate resistances to CRO (17.65\%), CN (17.65\%), TE (14.71\%), C (5.88\%), CIP (2.94\%), and AMC (2.94\%). Intermediate resistance means those Salmonella species were not

Table-2: Antibiotic susceptibility of drinking water Salmonella isolates.

\begin{tabular}{lccc}
\hline Antibiotics & \% Resistant & \% Intermediate & \% Susceptibility \\
\hline Chloramphenicol & 2.94 & 5.88 & 91.18 \\
Gentamicin & 2.94 & 17.65 & 79.41 \\
Vancomycin & 94.12 & 0.00 & 5.88 \\
Sulfamethoxazole/trimethoprim & 0.00 & 0.00 & 100.00 \\
Tetracycline & 0.00 & 14.71 & 85.29 \\
Erythromycin & 100.00 & 0.00 & 0.00 \\
Ciprofloxacin & 0.00 & 2.94 & 97.06 \\
Ceftriaxone & 11.76 & 17.65 & 70.59 \\
Amoxicillin/clavulanic acid & 23.53 & 2.94 & 73.53 \\
\hline
\end{tabular}


Table-3: Antibiotic resistance pattern of the Salmonella species.

\begin{tabular}{|c|c|c|c|}
\hline Code & Sources & $\begin{array}{l}\text { Antibiotic } \\
\text { resistance profile }\end{array}$ & $\begin{array}{l}\text { MAR } \\
\text { index }\end{array}$ \\
\hline D1 & Dam water & VA-E & 0.22 \\
\hline D2 & Dam water & VA-E & 0.22 \\
\hline D3 & Dam water & VA-E & 0.22 \\
\hline D4 & Dam water & VA-E & 0.22 \\
\hline D5 & Dam water & VA-E & 0.22 \\
\hline D6 & Dam water & VA-E & 0.22 \\
\hline $\mathrm{S} 1$ & Storage rain water & VA-E & 0.22 \\
\hline S2 & Storage rain water & VA-E & 0.22 \\
\hline T1 & Tap & VA-E & 0.22 \\
\hline T2 & Tap & VA-E & 0.22 \\
\hline T3 & Tap & VA-E & 0.22 \\
\hline T4 & Tap & VA-E & 0.22 \\
\hline T5 & Tap & VA-E & 0.22 \\
\hline T6 & Tap & VA-E & 0.22 \\
\hline D7 & Dam water & VA-E & 0.22 \\
\hline D8 & Dam water & VA-E & 0.22 \\
\hline D9 & Dam water & VA-E & 0.22 \\
\hline D10 & Dam water & VA-E & 0.22 \\
\hline D11 & Dam water & VA-E & 0.22 \\
\hline S3 & Storage rain water & VA-E & 0.22 \\
\hline S4 & Storage rain water & VA-E & 0.22 \\
\hline S5 & Storage rain water & VA-E & 0.22 \\
\hline S6 & Storage rain water & VA-E & 0.22 \\
\hline W1 & Well water & VA-E-AMC & 0.33 \\
\hline W2 & Well water & VA-E-AMC & 0.33 \\
\hline W3 & Well water & VA-E-AMC & 0.33 \\
\hline W4 & Well water & VA-E-AMC & 0.33 \\
\hline S7 & Storage rain water & VA-E-AMC & 0.33 \\
\hline D12 & Dam water & VA-E-CRO & 0.33 \\
\hline D13 & Dam water & VA-E-CRO & 0.33 \\
\hline D14 & Dam water & VA-E-C & 0.33 \\
\hline W5 & Well water & VA-E-CRO-AMC & 0.44 \\
\hline S8 & Storage rain water & VA-E-CRO-AMC & 0.44 \\
\hline W6 & Well water & VA-E-AMC-CN & 0.44 \\
\hline
\end{tabular}

$\mathrm{C}=$ Chloramphenicol, $\mathrm{CN}=$ Gentamicin, $\mathrm{VA}=$ Vancomycin, $\mathrm{E}=$ Erythromycin, $\mathrm{CRO}=$ Ceftriaxone, $\mathrm{AMC}=$ Amoxicillin/ clavulanic acid, MAR=Multiple antibiotic resistance

clearly resistant or susceptible, and such isolates have the tendency to easily become resistant $[29,30]$. It has also been indicated that in clinical diagnoses patients with intermediate results can be given a higher dosage of antibiotics $[29,30]$. The 34 Salmonella isolates also exhibited six different antibiotic resistant patterns. The patterns were VA-E, VA-E-AMC, VA-E-CRO, VA-E-C, VA-E-CRO-AMC, and VA-E-AMC-CN. The resistant pattern VA-E was the most common and was exhibited by 23 Salmonella isolates. Resistant to as high as four different antibiotics (VA-E-CRO-AMC and VA-E-AMC-CN) was exhibited by 3 Salmonella isolates. Salmonella species are important pathogens of global concern, and the emergence of antibiotic resistant strains is largely due to indiscriminate use of antibiotics in animal feeds as growth promoters and as therapeutic agents for treating humans and animals [31].

\section{Conclusion}

This study indicated that some drinking water sources for humans and animals in Tamale Metropolis are contaminated with Salmonella species. In addition, they are resistant to some antibiotics at different rates. Therefore, drinking water sources in Tamale Metropolis are potential sources for the transmission of Salmonella infection.

\section{Authors' Contributions}

FA designed the experiment. CKNA and HA performed all the experiments. FA analyzed the data and wrote the draft manuscript. All authors read and approved the final manuscript.

\section{Acknowledgments}

The authors are gratefully to the University for Development Studies, for allowing them to use the Spanish Laboratory to carry out this experiment. No fund was received from any institute for this study.

\section{Competing Interests}

The authors declare that they have no competing interests.

\section{References}

1. Adzitey F, Sumaila N, Saba CK. Isolation of E. coli from drinking water sources for humans and farm animals in Nyankpala Community of Ghana. Res J Microbiol 2015a;10:126-31.

2. Maheshwari N. Clinical Microbiology and Parasitology. $2^{\text {nd }}$ ed. New Delhi, India: Jaypee Brothers Medical Publishers; 2008. p. 272.

3. Sobsey MD, Bartram S. Water quality and health in the new millennium: The role of the World Health Organization Guidelines for Drinking-Water Quality. Forum Nutr 2003;56:396-405.

4. Organic Nutrition. The benefits of drinking water. Available from https://www.organicnutrition.co.uk/articles/benefits-of-drinking-water.htm. Accessed on 01-05-2016.

5. Adzitey F, Nafisah S, Haruna A. Antibiotic susceptibility of E. coli isolated from some drinking water sources in Tamale Metropolis of Ghana. Curr Res Bacteriol 2015b; 8:34-40.

6. Spellman FR, Drinan J. The Drinking Water Handbook. Lancaster, Pennsylvania, USA: Technomic Publishing Co., Inc.; 2000. p. 260.

7. World Health Organization. In: Cotruvo JA, Dufour A, Rees G, Bartram J, Carr R, Cliver DO, et al., editors. Waterborne Zoonosis: Identification, Causes and Control. London, UK: IWA Publishing; 2004. p. 95-111.

8. Wallace HA, Hammack TS. Salmonella in Bacteriological Analytical Manual. Available from: http://www.fda. gov/Food/ScienceResearch/LaboratoryMethods/ BacteriologicalAnalyticalManualBAM/UCM070149. Accessed on 01-06-2014.

9. Frederick A, Huda N. Salmonellas, poultry house environments and feeds: A review. J Anim Vet Adv 2011;10:679-85.

10. Adzitey F, Nsoah JK, Teye G. Prevalence and antibiotic susceptibility of Salmonella species isolated from beef and its related samples in Techiman Municipality of Ghana. Turk $\mathrm{J}$ Agric Food Sci Technol 2015c;3:644-50.

11. Anachinaba IA, Adzitey F, Teye GA. Assessment of the microbial quality of locally produced meat (beef and pork) in Bolgatanga Municipal of Ghana. Internet J Food Saf 2015;17:1-5.

12. Makwana PP, Nayak JB, Brahmbhatt MN, Chaudhary JH. Detection of Salmonella spp. from chevon, mutton and its environment in retail meat shops in Anand city (Gujarat), India. Vet World 2015;8:388-92.

13. Kalambhe DG, Zade NN, Chaudhari SP, Shinde SV, 
Khan W, Patil AR. Isolation, antibiogram and pathogenicity of Salmonella spp. recovered from slaughtered food animals in Nagpur region of Central India. Vet World 2016;9:176-81.

14. Papadopoulos T, Zdragas A, Mandilara G, Vafeas G, Giantzi V, Petridou E, et al. Characterization of Salmonella isolates from municipal sewage, patients, foods, and animals in Greece using antimicrobial susceptibility testing and pulsed field gel electrophoresis. Int J One Health 2016;2:12-8.

15. Addis Z, Kebede N, Worku Z, Gezahegn H, Yirsaw A, Kassa T. Prevalence and antimicrobial resistance of Salmonella isolated from lactating cows and in contact humans in dairy farms of Addis Ababa: A cross sectional study. BMC Infect Dis 2011;11:222.

16. Wegener HC. Antibiotic resistance linking human and animal health. In: Improving Food Safety Through a One Health Approach: Workshop Summary. Washington, DC: National Academies Press; 2012. p. 331-49. Available from: http://www.ncbi.nlm.nih.gov/books/NBK114485/. Accessed on 18-02-2014.

17. Jokinen C, Edge TA, Ho S, Koning W, Laing C, Mauro W, et al. Molecular subtypes of Campylobacter spp. Salmonella enterica, and Escherichia coli O157:H7 isolated from faecal and surface water samples in the Oldman River Watershed, Alberta, Canada. Water Res 2011;45:1247-57.

18. Dolejská M, Bierosová B, Kohoutová L, Literák I, Cízek A. Antibiotic-resistant Salmonella and Escherichia coli isolates with integrons and extended-spectrum beta-lactamases in surface water and sympatric black-headed gulls. J Appl Microbiol 2009;106:1941-50.

19. Obi CL, Potgieter N, Musie EM, Igumbor EO, Bessong PO, Samie A, et al. Human and environmental-associated non-typhoidal Salmonella isolates from different sources in the Venda Region of South Africa. Proceedings of the 2004 Water Institute of Southern Africa (WISA) Biennial Conference. 2004. p. 51-7.

20. Akinyemi KO, Iwalokun BA, Foli F, Oshodi K, Coker AO. Prevalence of multiple drug resistance and screening of enterotoxin (stn) gene in Salmonella enterica serovars from water sources in Lagos, Nigeria. Public Health 2011;125:65-71.
21. Adzitey F. Antibiotic classes and antibiotic susceptibility of bacterial isolates from selected poultry; A mini review. World's Vet J 2015a;5:36-41.

22. Abakpa GO, Umoh VJ, Ameh JB, Yakubu SE, Kwaga JK, Kamaruzaman S. Diversity and antimicrobial resistance of Salmonella enterica isolated from fresh produce and environmental samples. Environ Nanotech Monitory Mgt 2015;3:38-46.

23. Anonymous. Tamale Metropolis. Available from: http:// www.en.wikipedia.org/wiki/Tamale__ Ghana; 2014. Accessed on 18-02-2014.

24. Bauer AW, Kirby WM, Sherris JC, Turck M. Antibiotic susceptibility testing by a standardized single disk method. Am J Clin Pathol 1966;45:493-6.

25. Clinical and Laboratory Standards Institute. Performance Standards for Antimicrobial Disk and Dilution Susceptibility Tests for Bacteria Isolated from Animals Approved Standard CLSI Document VET01-A4. In Approved Standard. $4^{\text {th }}$ ed. Wayne, PA, USA: CLSI; 2013.

26. Krumperman PH. Multiple antibiotic resistance indexing of Escherichia coli to identify high-risk sources of fecal contamination of foods. Appl Environ Microbiol 1983;46:165-70.

27. Adentunde LA, Glover RL. Evaluation of bacteriological quality of drinking water used by selected secondary schools in Navorongo in Kassina-Nankana District in the Upper East Region of Ghana. Prim J Microbiol Res 2011;1:47-51.

28. World Health Organization. Microbial Aspect in Guideline for Drinking Water Quality. $3^{\text {rd }}$ ed. Geneva: WHO; 2006.

29. Adzitey F. Antibiotic resistance of Escherichia coli isolated from beef and its related samples in Techiman Municipality of Ghana. Asian J Anim Sci 2015b;9:233-40.

30. Adzitey F, Rusul G, Huda N, Cogan T, Corry J. Prevalence, antibiotic resistance and RAPD typing of Campylobacter species isolated from ducks, their rearing and processing environments in Penang, Malaysia. Int J Food Microbiol 2012;154:197-205.

31. Plym FL, Wierup M. Salmonella contamination: A significant challenge to the global marketing of animal food products. Rev Sci Tech 2006;25:541-54. 